\title{
The Relationship Between Employment And Real Exchange Rate: The Case Of Turkish Apparel Industry
}

Mehmet Huseyin Bilgin, (Email: mhbilgin@khas.edu.tr), Kadir Has University, Istanbul, Turkey Hakan Danis, (Email: hdanis@uga.edu), Terry College of Business, University of Georgia

\begin{abstract}
This paper investigates the relationship between employment and real exchange rate in Turkish apparel industry. In particular, the relationship between employment and real exchange rate is sophisticated than it seems. It is widely accepted that there exists a link between real exchange rate and employment. However, the literature on this relation is insufficient and there is no consensus on whether real exchange rate has positive or negative effect on employment. Yet, we know that the sign and magnitude of this relation depend on various conditions, which ought to be analyzed in detail. We lay out an empirical model using employment, real wage, real exchange rate and production series of Turkish apparel industry. Our results indicate that there is a positive relationship between employment and real exchange rate in the long run.
\end{abstract}

\section{INTRODUCTION}

xchange rate policies do not have effects solely on good, service and capital flows among countries. They have also important effects on inflation and unemployment. Indeed, the relationship among exchange rate, inflation, and unemployment has been analyzed by several economists. Campa and Goldberg (2001) mention, for instance, that there is a widespread belief among economists that real exchange rates have considerable effects on real side of the economy. Particularly, it is widely accepted that the flexible exchange rate affects labor market through import and export.

However, the studies analyzing the effects of exchange rate on employment are really insufficient. Besides, the results of these studies are complicated and most of these scarce studies are based on US economy. The starting point of these papers is the over appreciation of US Dollar in the first half of the 1980's.

One of the very best examples for these works is prepared by Branson and Love. Branson and Love (1987), in their work, investigate the effects of movements in exchange rates on employment and output of manufacturing industry. Their starting point is the over appreciation of US Dollar in the period of 1980-1985. They reach a conclusion that movements in real exchange rate have real impacts on employment in manufacturing industry and it leads to employment losses especially in durable good industries. Based on this study, they argue that appreciation in dollar in period 1980-1985 gave rise to approximately 1 million employment losses in United States.

One of the important studies in this field is done by Revenga. Revenga (1992), using manufacturing data, states that exchange rates have important influence on employment in United States. He finds that domestic labor market is negatively affected especially by over appreciation in US Dollar. According to him, a 40 percent appreciation in real exchange rates leads to $4.5 \%-7.5 \%$ decrease in employment in import competitive markets between 1980 and 1985.

Another study on investigating the impact of changes in exchange rates on employment in manufacturing industry is made by Becher and Chmura. Becher and Chmura (1990), in their work, aim to explain the effects of appreciation in US dollar on employment in rural area manufacturing industry. To reach a conclusion, they analyze 
the possible effects of appreciation state by state. They observe that between 1980 and 1985, when the US Dollar appreciates, the decrease in employment in rural manufacturing industry is more than the decrease in urban areas. They mention that the labor abundant industries are mostly in rural areas. They suggest, that's why, manufacturing industry operating in rural areas are affected more.

Despite these studies showing a strong relationship between labor market and exchange rates, there are also studies that show this relationship is not that strong. Campa and Goldberg (2001) is a good example for this kind of studies. Campa and Goldberg (2001) determine that there exists a weak relation between US dollar and employment. The study includes last 21 years and elasticity of employment respect to real exchange rate is stated as -0.01 which indicates a fairly weak relationship. Furthermore, this relationship varies from industry to industry.

The goal of our study is to investigate the effect of changes in real exchange rate on employment in the Turkish apparel industry. In Turkey, where the stability of exchange rates has not been achieved and the unemployment is very high, the investigation of this relationship is clearly crucial. The crises that Turkey experiences in last decade increase the importance of the issue more. There are two reasons why the apparel sector is chosen. First, by its creating employment capacity and its export size, apparel sector has a very important place in Turkish economy. Second, since it is a labor-abundant sector, employment in apparel sector is more likely to be influenced by changes in exchange rates.

As it is understood from the referred works above, the results of the studies on the relationship between exchange rates and employment can be very distinct. Yet, there is a widespread consensus in economics literature that there is a negative relationship between real exchange rates and employment. Nevertheless, the result of our work is different from the general tendency. We found that there is positive long run relation between real exchange rate and employment in Turkish apparel industry. It is very normal to reach this conclusion since there are numerous economic and institutional factors that affect employment. Moreover, relationship between real exchange rate and employment is very complicated and can be reached different results depending on social and economic features of countries.

The plan of the paper is as follows. First, the effects of changes in exchange rates on labor market are investigated theoretically. In this framework, how changes in exchange rates affect employment level receives priority consideration. Then, with the help of econometric model, the relation between real exchange rate, employment, export and real wage is investigated in the case of Turkish apparel industry. In the last part, the results of our study are evaluated.

\section{THEORETICAL DISCUSSION}

Theoretically, natural rate of unemployment and equilibrium real exchange rate are determined by various economic and institutional factors. It is, however, understood that real exchange rate has significant role on determining export, production, wage, and employment. Not only the discussion on literature but also the empirical studies on this field reveal that exchange rate is a significant factor that affects especially employment/unemployment. The effects of variation in exchange rates on labor market activities such as wages and employment are tested empirically, too.

Under the assumption of (downward) sticky-wages, it can be proposed that real exchange rate is negatively related with output and employment (positive relation between real exchange rate and unemployment). However, it is noteworthy that the relation between exchange rates and labor market activities can differ from industry to industry. Campa and Goldberg (2001) denote that this relation is stronger in certain industries. As they claimed, this relation is definitely stronger in export-oriented industries. Moreover, in industries using mainly import inputs, the (contractionary or expansionary) effect of exchange rates on labor demand will be more severe. On the other hand, in industries where highly educated labor force employed, this relation is less powerful.

Especially in open economies, beside other factors, the real exchange rate is one of the most important factors that affect employment because as Lindblad and Sellin (2003) point out, in open economies consumers have an opportunity to prefer both import and domestic goods. Gordon (1981) claims that exchange rates affect labor market 
through imports and exports. Goldberg and Tracy (1999) accept this idea and add that exchange rates affect employment through import inputs and export revenues. According to them, the structure of the industry and the elasticities of labor market also affect this relation.

As Leichenko and Silva (2004) emphasize, it is expected that decrease in real exchange rates (or cheap export) increases exports and causes high employment and income level. In other words, appreciated exchange rate (cheap import) leads to lower employment and income level. In this mechanism, export and import prices are definitely important. Frenkel (2004) mentions that depreciation in real exchange rates, ceteris paribus; increases export in the short run and leads to more demand in domestic activities and higher production and employment level. In addition, the magnitude of this effect depends on the idle capacity and unemployment level of the economy.

Campa and Goldberg (2001) make the point that changes in exchange rates influence labor demand of the industry by affecting marginal profits of firms. In this analysis, it is assumed that depreciation in real exchange rates affects the revenues of export-oriented firms positively. On the other hand, depreciation in real exchange rates (loosing value of national money) causes import goods become more expensive relative to domestic goods and it urges consumers to substitute import in favor of domestic goods. Therefore, increase in demand for domestic goods will definitely increase employment.

Provided that the imports become expensive, in industries where import inputs are being used, cost of labor decreases relatively. It should, theoretically, lead to increase in employment. Frenkel (2004) concludes that real exchange rates influence labor demand (concentration) by changing the relative price of labor-capital. Thus, depreciation in real exchange rates increases labor concentration (labor-capital ratio). However, it should be noted that devaluation causes import inputs to become more expensive and it may lead to inflation, which may decrease employment by shrinking the aggregate demand.

When the real exchange rate appreciates, the employment growth in traded-sectors falls. Gourinchas (1999) states in his study on manufacturing industry in France that 1 percent appreciation in exchange rates brings about 35 thousand employment loss in traded-sectors. Based on a study on United States, Leichenko and Silva (2004) observe that it is clear that cheap export has an expansionary effect on employment; however, the effect of cheap import on employment is not that clear. On the other hand, Frenkel (2004) argues that real exchange rate affects employment via affecting economic growth. He, however, adds that this effect happens in the long run.

It is theoretically presumed that fluctuations in exchange rates affect economic development and labor market negatively in the short run. Fluctuation in exchange rates leads to uncertainty in the short run and increases costs. This uncertainty, naturally, makes difficult to take decision for firms. Therefore, if the instability of exchange rates (thus, the uncertainty) vanishes, economic agents can take their decisions more precisely. This affects export, production and employment positively. Provided that increase in export is supported by new investments, it is clear that its employment raising effect will be much more. In this respect, Buscher and Mueller (1997) propose that there is a linear relationship between exchange rate stability, foreign trade and employment level.

Carr and Floyd (2001) suggest that an exogenous shock like a fall in price of goods in trade partner country increases unemployment in the short run, under the sticky wages and prices assumption. Moreover, when an exogenous shock hits the economy it is easier to adjust the exchange rates compared to adjusting domestic prices and wages because in the short run nominal wages and prices are presumed downwardly inflexible. Thus, in case of any exogenous shock, it is easier to change the nominal exchange rates and so, change the terms of trade. In this respect, Belke and Gros (1999) argue that since the exogenous shocks are absorbed by adjusting exchange rates, they have small effects on unemployment. This situation is obviously valid under flexible exchange rate systems.

Exchange rates affect not only employment level but also other activities of labor market. The effects of exchange rates on labor market are materialized mainly through export and import. Indeed, increase in import or increase in competition between import and domestic goods affects the relationship between employers and employees, especially the wage contracts. Increase in competition may cause to shelve several rights and policies related with unwritten wage, business and working conditions. 
Goldberg and Tracy (1999) mention that exchange rates affect not only employment but also wages. Depreciation in national currency increases wages because exchange rates affect labor concentration by changing the relative prices of inputs. On the other hand, Campa and Goldberg (2001) state that wages are considerably sensitive to exchange rates than employment. Indeed, studies on this area show us real exchange rates have effects on wages although this relation is not as strong as the relation between real exchange rates and employment. The study by Bertrand (1999) indicates that 10 percent increase in competition between import and domestic goods leads to 1.6 percent decrease in wages and increases unemployment. Therefore, we may say that wages of employees are affected by the labor market conditions in the trade partner countries.

\section{EMPIRICAL RESULTS}

Our empirical analysis uses quarterly data and encompasses the time period between 1995:1 and 2004:2. All the variables, employment, production, real wage, and real exchange rate in apparel industry as an index, are in logarithm form and all the data is obtained from the State Institute of Statistics (SIS) and The Central Bank of Republic of Turkey (TCMB). The variation of all these variables can be seen in Figure 3.1.

Before starting in estimation model, we analysed stationarity of the variables involved in the analysis because in estimation it is crucial to analyse whether the variables included are stationary or not. In case of nonstationary, the variance and the mean of the variable $\left(X_{t}\right)$ will be no more constant over time and covariance between $X_{t}$ and $X_{t-s}(s \neq$ 0 ) will not be zero or dependent only on the lag(s) but will be dependent on t. As Phillips (1987) states, the importance of finding the nonstationarity comes from the property that using the nonstationary variables in the estimation may cause spurious regression.

In literature, there are several unit root tests to find out if the series are stationary or not. This paper will use Augmented Dickey Fuller (ADF) Test and in case of any hesitation Kwiatkowski, Phillips, Schmidt and Shin (KPSS) test will be employed. ${ }^{1}$ This paper does prefer ADF since it is a widely accepted unit root test among econometricians. KPSS is used as its alternative since it assumes the series is stationary under the null hypothesis while ADF assumes it nonsationary under the null. Therefore, it will be a good alternative for ADF test in case of any waver. The lag length in ADF test is determined by Schwartz Informaion Criteria (SIC).

One may expect seasonally adjusted series to be used in the unit root tests if the series exhibit seasonality. However, this paper uses unadjusted series based on the finding of Ghysels (1990) and Ghysels and Perron (1993) which indicate that seasonal adjustment may lead to accept the existence of unit root when there is actually no unit root in the series.

The ADF and KPSS tests results are presented in Table 3.1 and Table 3.2, respectively. According to ADF and KPSS unit root test results all the variables are integrated of order one, I(1), which means that after taking their first differences the series become stationary. ${ }^{2}$

As it is seen, one can notice the difference between Figure 3.1 and Figure 3.2, which shows the variables in the level and in the first difference, respectively. After taking the first differences it can be visually inspected that the variables exhibit more stationary path.

Although economics literature tells us one way of getting rid off the unit root problem is using the first differences, since we have limited data for this analysis, taking first difference brings about important information loss. Moreover, our analysis pay more attention on longrun relationship between depended and explanatory variables. As Granger (1981) and Engle and Granger (1987) prove, the linear combination of variables having I(1) property may

\footnotetext{
${ }^{1}$ The critical values for ADF and KPSS tests are tabulated in MacKinnon (1996) and Kwiatkowski et al. (1992).

${ }^{2}$ According to ADF test, although the production series is non-stationary in "none" and "intercept" cases, the series is stationary in "trend \& intercept" case. Therefore, we use KPSS in order to be sure if the series is non-stationary or not. Based on KPSS test, it is non-stationary in "intercept" case at the $1 \%$ significance level and non-stationary in "trend \& intercept" case at the $5 \%$ significance level. After first difference, the production series become definitely stationary. Hence, it is also I(1). Moreover, the real wage is I(1) at the $1 \%$ significance level except for the "trend \& intercept" case where it is non-stationary at the 5\% significance level which fairly enough to be considered as I(1) following the usual convention.
} 
exhibit stationary $(\mathrm{I}(0))$ process. If the linear combination of the variables is stationary, the variables are said to be cointegrated. Therefore, it is more appropriate to analyse if there exists a cointegration which gives us the long run relationship using the variables in their level form. By this way, we can find if there exists a longrun relationship between the variables without loosing any important information.

The model is

$\log \mathrm{EMP}=\alpha+\beta \log \mathrm{PROD}+\partial \log \mathrm{RW}+\delta \log \mathrm{RER}+\epsilon$

Where EMP, PROD, RW, RER indicate Employment, Production, Real Wage, and Real Exchange Rate, respectively. $\beta, \partial$ and $\delta$ are parameters, $\alpha$ is a constant term and $\epsilon$ is a stochastic disturbance term.

In case of cointegration the linear combination of these variables must be stationary. In other words, if there exists a long run relationship between these series, the error term $\epsilon$ will be stationary. Therefore, analysing if the error term $\epsilon$ is stationary will give us whether we have a long run relationship or not. This approach is known as EngleGranger (EG) test or Augmented Engle-Granger (AEG) test based on applying Dickey-Fuller (DF) test or ADF unit root test, respectively. If ADF test states that $\epsilon$ is stationary it means that the series are cointegrated. Nevertheless, this time in DF and ADF tests, the standard critical values are not appropriate since the estimated error term $\epsilon$ depends on several parameters namely, $\beta, \partial$ and $\delta$. Hence, we will use the critical values for EG which MacKinnon (1991) produces. ${ }^{3}$

The AEG test suggests that the estimated error term $\epsilon$ is stationary which means the series are cointegraed. In other words, there is a longrun relationship between employment, production, real wage and real exchange rate. In case of any divergence from its long run path, it will be temporary. The AEG test results are given in Table 3.3.

By using AEG test results which indicate the existence of cointegration, we can construct the model in their level form. Put another way, by observing the cointegration relationship does exist, the model constructed in level form will no longer spurious and therefore, the $t$ and $F$ statistics will be valid for significance testing.

The estimated cointegration model results as follows: ${ }^{4}$

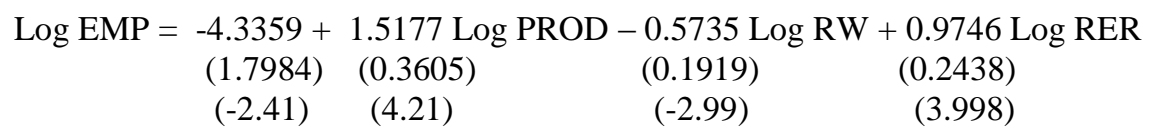

$\mathrm{R}^{2}=0.7313$

Where the parantheses in the first raw are the standard errors and in the second raw are the t values of the estimated parameters. Since the functional form of the estimated model is log linear, the parameters gives the elasticities. For instance, a $10 \%$ appreciation in real exchange rates give rise to $9.7 \%$ increase in employment, a $10 \%$ increase in production causes $15 \%$ increase in employment, a $10 \%$ increase in real wages is associated with $5.7 \%$ decrease in employment and so forth. Moreover, according to our estimated model results there is a positive relationship between employment and production, negative relationship between employment and real wage and positive relationship between employment and real exchange rate. All the relationships except the employment-real exchange rate are consistent with the economics literature. However, we can not say that positive relationship between employment and real exchange rate contradicts with the economic literature because the sign and magnitude of this relation depends on various conditions and there are also several studies showing positive relationship. However, the rationale behind this relationship must be considered in more detail.

\footnotetext{
${ }^{3}$ The critical values for EG can also be found in Patterson (2000).

${ }^{4}$ The result of the estimated model is shown Table 3.4 in more detail.
} 


\section{CONCLUSION}

In this paper, we have tried to provide theoretical and empirical evidence about the relation between real exchange rates and employment. In particular, the relationship between employment and real exchange rate is a cumbersome issue. It is well known that there is a link between real exchange rate and employment and there is a widespread belief among economists that real exchange rates have considerable effects on real side of the economy. However, the studies analyzing the effects of exchange rate on employment is really insufficient. The results of these studies are also complicated and apart from each other due to several reasons. There is no perfect consensus on whether real exchange rate has positive or negative effect on employment. All we know is that the sign and magnitude of this relation depends on various conditions, which ought to be analyzed in more detail.

The real exchange rate has many complex impacts on real and nominal side of the economy through different transmission mechanisms. Therefore, calculating the sign and the magnitude of the total effect is very difficult. Its sign and magnitude may differ from sector to sector and from country to country depending on the structure of the economies. We have demonstrated that there is a long run relationship between real exchange rate and employment in Turkish apparel industry. However, the interesting result of the paper is that we have found a positive long run relation, which is different from most of the empirical studies in economics literature.

\section{REFERENCES}

1. Bechter, D. M. and C. Chmura (1990). The Competitiveness of Rural County Manufacturing During a Period of Dollar Appreciation. Working Paper 90-4. Federal Reserve Bank of Richmond.

2. Belke, A. and D. Gros (1999). Estimating the Costs and Benefits of EMU: The Impact of External Shocks and Labour Markets. Weltwirtschaftliches Archiv. Vol. 135 (1). pp. 1-47.

3. Bertrand, M. (1999). From the Invisible Handshake to the Invisible Hand? How Import Competition Changes the Employment Relationship. NBER Working Paper Series. No. 6900.

4. Branson, W. H. and J. P. Love. (1987). The Real Exchange Rate and Employment in U.S. Manufacturing: State and Regional Results. NBER Working Paper Series. No. 2435.

5. Buscher, H. S. and C. Mueller. (1997). Exchange Rate Volatility Effects on the German Labour Market: A Survey of Recent Results and Extensions. Discussion Paper Series. No. 37. Institute For The Study Of Labor.

6. Campa, J. M. and L. S. Goldberg, (2001). Employment versus Wage Adjustment and the U.S. Dollar. Review of Economics and Statistics. 83(3). pp. 477-489.

7. Carr, J. L. and J. E. Floyd. (2001). Real and Monetary Shocks to the Canadian Dollar: Do Canada and the U.S. Form an Optimal Currency Area. Working Paper. Department of Economics and Institute for Policy Analysis. University of Toronto.

8. Engle, R. F. and C. W. I. Granger. (1987). Co-Integration and Error Correction: Representation, Estimation, and Testing. Econometrica. 55. pp. 251-276.

9. Frenkel, R. (2004). Real Exchange Rate and Employment in Argentina, Brazil, Chile and Mexico. http://www.g24.org/fren0904.pdf.

10. Ghysels, E. (1990). Unit Root Tests and the Statistics Pitfalls of Seasonal Adjustment: The Case of US Post War Real GNP. Journal of Business and Economic Statistics. 8. pp. 145-152.

11. Ghysels, E. and P. Perron. (1993). The Effect of Seasonal Adjustment Filters on Tests for a Unit Root. Journal of Econometrics. 55. pp. 57-98.

12. Goldberg, L. and J. Tracy. (1999). The Mechanisms for Exchange Rate and Wage Interaction. http://www.nber.org/ confer/99/itisi99/goldberg.pdf.

13. Gordon, R. J. (1981). Inflation, Flexible Exchange Rates, and the Natural Rate of Unemployment. NBER Working Paper Series. No. 708.

14. Gourinchas, P. O. (1999). Exchange Rates Do Matter: French Job Reallocation and Exchange Rate Turbulence, 1984-1992. European Economic Review. Vol. 43. pp.1279-1316.

15. Granger, C. W. I. (1981). Some Properties of Time Series Data and Their Use in Econometric Model Specification. Journal of Econometrics. 16. pp. 121-130.

16. Kwiatkowski, D., P. C. B. Phillips, P. Schmidt, and Y. Shin. (1992). Testing the Null Hypothesis of Stationarity Against the Alternative of a Unit Root. Journal of Econometrics. 54. pp. 159-178. 
17. Leichenko, R. and J. Silva, (2004). International Trade, Employment and Earnings: Evidence from US Rural Countries. Regional Studies. Vol. 38 (4). pp.355-374.

18. Lindblad, H. and P. Sellin. (2003). The Equilibrium Rate of Unemployment and the Real Exchange Rate: An Unobserved Components System Approach. Working Paper Series. No. 152. Sveriges Riksbank.

19. MacKinnon, J. G. (1991). Critical Values for Cointegration Tests, in R.F. Engle and C. W. J. Granger (eds) (1991). Long-run Economic Relationships. Oxford University Press. Oxford. pp. 267-276.

20. MacKinnon, J. G. (1996). Numerical Distribution Functions for Unit Root and Cointegration Tests. Journal of Applied Econometrics. 11. pp. 601-618.

21. Patterson, K. (2000). An Introduction to Applied Econometrics: A Time Series Approach. St. Martin's Press. USA.

22. Phillips, P.C.B. (1987). Time Series Regressions with Unit Roots. Econometrica. 55. pp. 277-302.

23. Revenga, A. (1992). Exporting jobs? The Impact of Import Competition on Employment and Wages in US Manufacturing. Quarterly Journal of Economics. 107 (1). pp.255-284.

\section{Appendix}

\section{A. Figures}
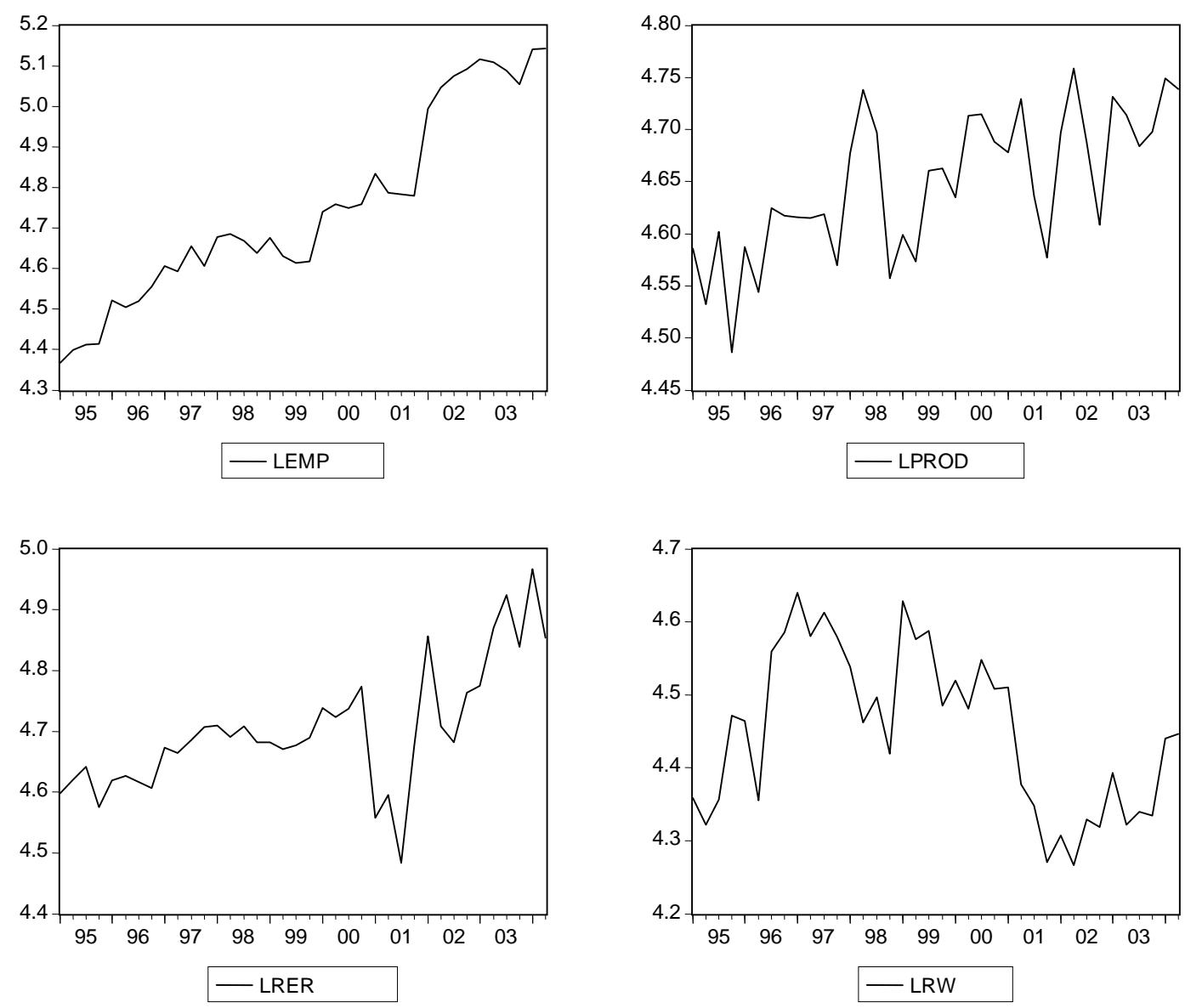
Figure 3.1 Graphs of Variables (In Level)
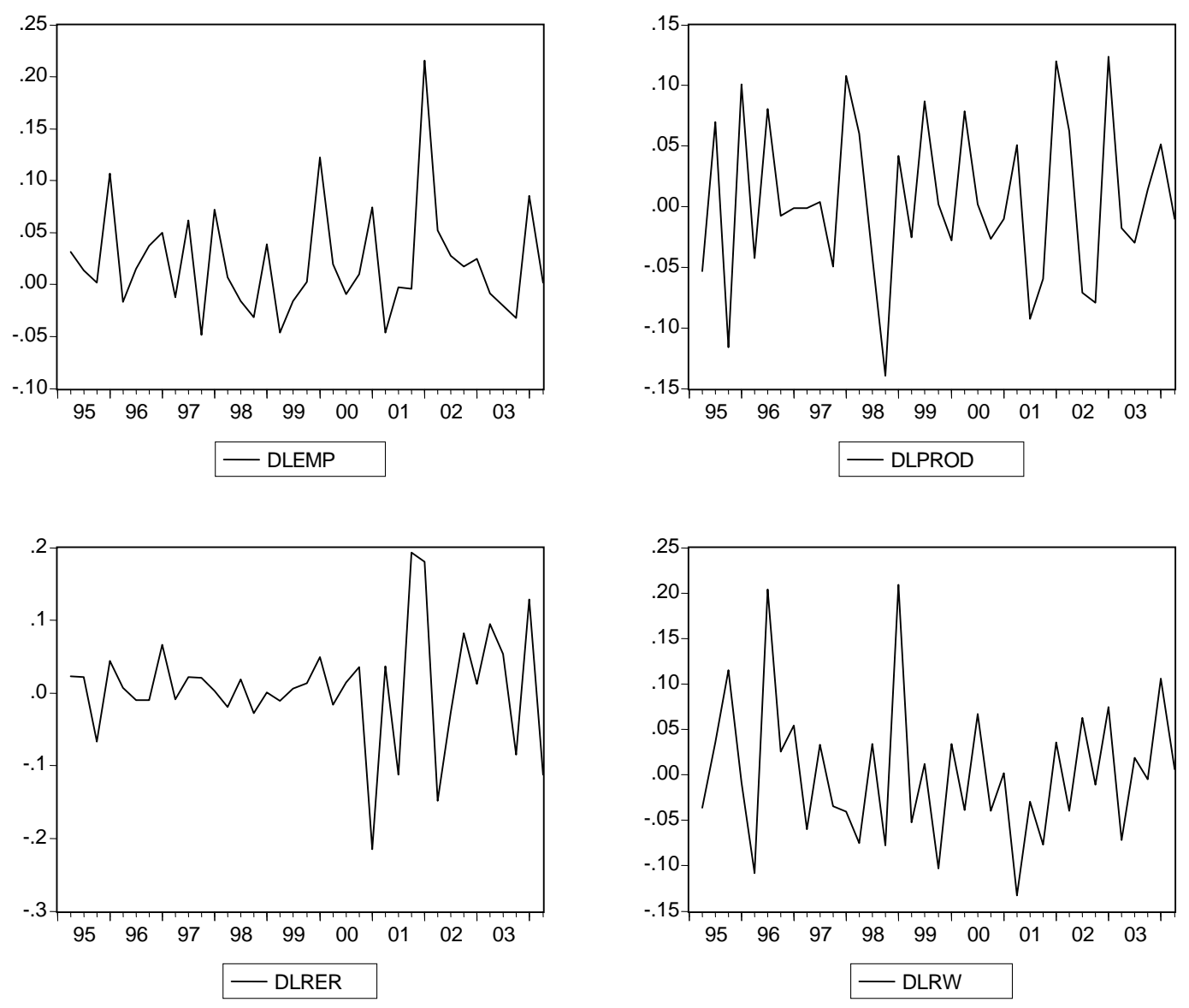
FIGURE 3.2 Graphs of Variables (In First Difference)

B. Tables

Table 3.1 ADF Unit Root Test Results

\begin{tabular}{|c|c|c|c|c|c|c|}
\hline & & & \multicolumn{4}{|c|}{ NONE } \\
\hline & & & LEMP & LPROD & LRER & LRW \\
\hline \multirow{4}{*}{ LEVEL } & Test Statistic & & 2.377842 & 0.682317 & 0.487646 & -0.062532 \\
\hline & Critical & $1 \%$ & -2.628961 & -2.632688 & -2.628961 & -2.634731 \\
\hline & & $5 \%$ & -1.950117 & -1.950687 & -1.950117 & -1.951000 \\
\hline & Lags included & & 0 & 2 & 0 & 3 \\
\hline \multirow{4}{*}{$\begin{array}{l}\text { FIRST } \\
\text { DIFFERENCE }\end{array}$} & Test Statistic & & -5.831433 & -6.487025 & -7.647529 & -4.325461 \\
\hline & Critical & $1 \%$ & -2.630762 & -2.632688 & -2.630762 & -2.634731 \\
\hline & & $5 \%$ & -1.950394 & -1.950687 & -1.950394 & -1.951000 \\
\hline & Lags included & & 0 & 1 & 0 & 2 \\
\hline
\end{tabular}

\begin{tabular}{|l|c|c|c|c|c|c|}
\hline & & & \multicolumn{4}{|c|}{ INTERCEPT } \\
\hline & & & LEMP & LPROD & LRER & LRW \\
\hline \multirow{4}{*}{ LEVEL } & Test Statistic & & -0.608841 & -3.218703 & -2.377571 & -1.383495 \\
\cline { 2 - 7 } & Critical & $1 \%$ & -3.621023 & -3.621023 & -3.621023 & -3.639407 \\
\cline { 2 - 7 } & & $5 \%$ & -2.943427 & -2.943427 & -2.943427 & -2.951125 \\
\cline { 2 - 7 } & Lags included & & 0 & 0 & 0 & 3 \\
\hline \multirow{3}{*}{$\begin{array}{l}\text { FIRST } \\
\text { DIFFERENCE }\end{array}$} & Test Statistic & & -6.691329 & -6.474865 & -7.625477 & -4.253819 \\
\cline { 2 - 7 } & Critical & $1 \%$ & -3.626784 & -3.632900 & -3.626784 & -3.639407 \\
\cline { 2 - 7 } & & $5 \%$ & -2.945842 & -2.948404 & -2.945842 & -2.951125 \\
\cline { 2 - 7 } & Lags included & & 0 & 1 & \multicolumn{2}{c}{2} \\
\hline
\end{tabular}

\begin{tabular}{|l|c|c|c|c|c|c|}
\hline & & & \multicolumn{4}{|c|}{ TREND \& INTERCEPT } \\
\hline & & & LEMP & LPROD & LRER & LRW \\
\hline \multirow{4}{*}{ LEVEL } & Test Statistic & & -2.388047 & -4.866566 & -3.413456 & -3.045601 \\
\cline { 2 - 7 } & Critical & $1 \%$ & -4.226815 & -4.234972 & -4.226815 & -4.243644 \\
\cline { 2 - 7 } & & $5 \%$ & -3.536601 & -3.540328 & -3.536601 & -3.544284 \\
\cline { 2 - 7 } & Lags included & & 0 & 1 & 0 & -2 \\
\hline \multirow{3}{*}{$\begin{array}{l}\text { FIRST } \\
\text { DIFFERENCE }\end{array}$} & Test Statistic & & -6.596944 & -6.373851 & -7.536952 & -4.088306 \\
\cline { 2 - 8 } & Critical & $1 \%$ & -4.234972 & -4.243644 & -4.234972 & -4.252879 \\
\cline { 2 - 8 } & & $5 \%$ & -3.540328 & -3.544284 & -3.540328 & -3.548490 \\
\cline { 2 - 8 } & Lags included & & 0 & 1 & 0 & 2 \\
\hline
\end{tabular}

Table 3.2 KPSS Test Results for the Variable LPROD

\begin{tabular}{|c|c|c|c|c|}
\hline & & & INTERCEPT & TREND \& INTERCEPT \\
\hline & & & LPROD & LPROD \\
\hline \multirow{3}{*}{ LEVEL } & Test Statistic & & 0.738340 & 0.156548 \\
\cline { 2 - 5 } & Critical & $1 \%$ & 0.739000 & 0.216000 \\
\cline { 2 - 5 } & & $5 \%$ & 0.463000 & 0.146000 \\
\hline \multirow{2}{*}{ FIRST } & Test Statistic & & 0.236317 & 0.218958 \\
\cline { 2 - 5 } DIFFERENCE & Critical & $1 \%$ & 0.739000 & 0.216000 \\
\cline { 2 - 5 } & & $5 \%$ & 0.463000 & 0.146000 \\
\hline
\end{tabular}

Table 3.3 AEG Test Results

\begin{tabular}{|c|c|c|c|c|}
\hline & & & INTERCEPT & TREND\&INTERCEPT \\
\hline \multirow{3}{*}{ LEVEL } & Test Statistic & & -4.055968 & -4.596051 \\
\cline { 2 - 5 } & Critical & $10 \%$ & -4.03957 & -4.45637 \\
\cline { 2 - 5 } & Lags included & & 0 & 0 \\
\hline
\end{tabular}


Table 3.4 The Estimated Cointegration Model

\begin{tabular}{|c|c|c|c|c|}
\hline \multicolumn{5}{|c|}{ Dependent Variable: LEMP } \\
\hline \multicolumn{5}{|c|}{ Method: Ordinary Least Squares } \\
\hline \multicolumn{5}{|c|}{ Sample: 1995:1 2004:2 } \\
\hline Variable & Coefficient & Std. Error & t-Statistic & Prob. \\
\hline $\mathbf{C}$ & -4.335871 & 1.798455 & -2.410887 & 0.0215 \\
\hline LPROD & 1.517720 & 0.360530 & 4.209686 & 0.0002 \\
\hline LRER & 0.974603 & 0.243759 & 3.998221 & 0.0003 \\
\hline LRW & -0.573505 & 0.191898 & -2.988599 & 0.0052 \\
\hline $\mathbf{R}^{2}$ & 0.731301 & \multicolumn{2}{|c|}{ Mean Dependent Variable } & 4.747300 \\
\hline Adjusted R $^{2}$ & 0.707593 & \multicolumn{2}{|c|}{ S.D. Dependent Variable } & 0.233488 \\
\hline S.E. of regression & 0.126258 & \multicolumn{2}{|c|}{ AIC } & -1.201676 \\
\hline S. squared resid & 0.541998 & \multicolumn{2}{|l|}{ SIC } & -1.029299 \\
\hline Log likelihood & 26.83185 & \multicolumn{2}{|l|}{ F-statistic } & 30.84526 \\
\hline Durbin-Watson stat & 1.078061 & \multicolumn{2}{|l|}{ Prob (F-statistic) } & 0.000000 \\
\hline
\end{tabular}

\section{NOTES}

